\title{
MICHAŁ ŚWIDNICKI ${ }^{1}$
}

\section{Sprawozdanie z Ogólnopolskiej Konferencji Naukowej „Prywatna ochrona bezpieczeństwa”}

26 listopada 2015 roku w Kolegium Prawa Akademii Leona Koźmińskiego w Warszawie odbyła się Ogólnopolska Konferencja Naukowa organizowana w ramach realizacji grantu Opus 5 Narodowego Centrum Nauki pt.: „Prywatna ochrona bezpieczeństwa i jej normy. Niepaństwowe prawo?", objęta patronatem Dziennika Gazety Prawnej, kierowana do naukowców zajmujących się problematyką bezpieczeństwa, praktyków z branży ochrony, detektywów, przedstawicieli władz i organizacji pozarządowych, a także studentów. Pomysłodawcą i organizatorem wydarzenia była kierująca grantem prof. dr hab. Jolanta Jabłońska-Bonca, specjalista z zakresu teorii i filozofii prawa oraz prywatnej ochrony bezpieczeństwa. Celem konferencji była wymiana poglądów, doświadczeń praktyków i teoretyków z zakresu prywatnej ochrony bezpieczeństwa, ale przede wszystkim nawiązanie współpracy wszystkich środowisk zainteresowanych tematyką bezpieczeństwa.

Konferencję otworzył Rektor ALK prof. dr hab. Witold Bielecki, który zwrócił uwagę na to, że omawiane zagadnienie: „Idealnie wpisuje się w obecną sytuację geopolityczną na świecie” i tematyka konferencji jest aktualna, „(...) stanowi wyzwanie dla całej Europy, żeby wprowadzić takie bezpieczeństwo, które byłoby skuteczne, a zarazem demokratyczne”. Jak określił minister Andrzej Lewiński: „stanowiłyby zapukanie do drzwi ustawodawcy i poproszenie o należne prawa np. dla środowiska detektywistycznego". Pierwszym referentem był ppłk Straży Granicznej Andrzej Prokopski, który zaprezentował temat „Współpraca w zakresie ochrony lotnisk. Nowe doktryny bezpieczeństwa a prywatyzacja ochrony”. W swoim wystąpieniu przedstawił kompetencje funkcjonariuszy Staży Granicznej i zadania, jakie mają oni do wykonania podczas odbywania służby, a także zapewnił, że: „Nawet po przekazaniu kontroli nad bezpieczeństwem lotnisk podmiotom pry-

1 Michał Świdnicki - student prawa w Kolegium Prawa, Akademia Leona Koźmińskiego, Warszawa, Polska (e-mail: michal_swidnicki@wp.pl). 
watnym, Straż Graniczna jest jednym z głównych podmiotów odpowiedzialnych za bezpieczeństwo, a wprowadzone rozwiązania w zakresie nadzoru są skuteczne i w pełni bezpieczne". Gen. dr Jacek Pomiankiewicz w swoim wystąpieniu zasygnalizował problemy, jakie powstają przy okazji tworzenia prywatnych zakładów karnych na świecie. „Kadra więzienna ma dwojakie podejście do tego zagadnienia, niektórzy widzą w tym możliwości, a inni są niechętni, obawy wiążą się z brakiem doświadczenia prywatnego podmiotu zarówno w budowie, jak i zabezpieczeniu obiektu czy możliwością nadmiernego oszczędzania - to wszystko może przynieść negatywne konsekwencje prywatyzowania zakładów karnych". Generał oszacował roczny koszt utrzymania więźnia w Polsce na 34500 zł. Jest to wysoki wydatek państwa i prywatne zakłady karne mogłyby obniżyć ten koszt nawet o 20 procent. Prof. dr hab. Stanisław Koziej mówił o hipotetycznej sytuacji zagrożenia państwa, o strategicznej odporności kraju w przypadku zagrożeń. Przedstawił pogląd na temat różnego rodzaju organizacji pozamilitarnych, w tym prywatnych agencji ochrony, że w momencie zagrożenia, takie organizacje: „(...) mogłyby doraźnie pomagać armii, realizować zadania ochrony kraju", ale żeby to uczynić, należałoby wprowadzić odpowiednie regulacje, np. rozpisanie planów operacyjnych. Dr Wiesław J. Modrakowski, prezes zarządu Polskiego Stowarzyszenia Licencjonowanych Detektywów oraz mgr Marcin Berent z Katedry Prawa Karnego i Polityki Kryminalnej WPiA UMK w Toruniu przedstawili problemy, z jakimi zmaga się Stowarzyszenie. Tematem wystąpienia był kodeks etyki detektywa w kontekście standardu minimalnego. Mgr Marcin Berent nawiązywał w wystąpieniu do ustawy o usługach detektywistycznych i deregulacji zawodu detektywa. Konkluzją, nasuwającą się po przedstawieniu argumentów, było przywrócenie egzaminu na detektywa, jak i wymóg nieskazitelnego charakteru, podwyższenie standardów usług detektywistycznych poprzez większe obostrzenia w dostępie do zawodu. Postulowano napisanie nowej ustawy „dającej detektywom uprawnienia, które dawno powinni posiadać". Mgr Sławomir Wagner, prezes Zarządu Polskiej Izby Ochrony, przedstawił zagadnienie ochrony komercyjnej, opisywał np. fakt utraty uprawnień po 5 latach pracy przez pracowników ochrony i wymogu odbycia ponownego kursu zawodowego. Prelegent także postulował przygotowanie nowej ustawy, która szanowałaby godność pracownika ochrony: „Powinien obowiązywać jeden akt precyzyjny, który zawierałby wszystkie zasady udzielania koncesji i wykonywania pracy przez pracowników ochrony". Ostatnią wypowiedzią w sesji porannej było wystąpienie Dominiki Pasji, studentki prawa ALK, która przedstawiła wyniki badań Studenckiej Prawniczej Grupy Badawczej ALK.

Sesję popołudniową konferencji rozpoczęli prof. dr hab. Zdzisław Brodecki i dr Sylwia Jaśkiewicz-Kamińska, przedstawiciele Wydziału Prawa Wyższej Szkoły Bankowej w Gdyni. Tematem była odpowiedzialność za ochronę infrastruktury 
krytycznej. Profesor stwierdził, że: „Prawo nie jest w stanie sprostać wyzwaniom, zwłaszcza w dziedzinie bezpieczeństwa, jest tylko cząstką systemu i nie odgrywa $\mathrm{w}$ nim istotnej roli: doktryny wojenne są przestarzałe, istnieje prawo weta w Radzie Bezpieczeństwa”. Dr Sylwia Jaśkiewicz-Kamińska zwróciła uwagę, że: „(...) w przypadku infrastruktury krytycznej mamy do czynienia z przerzucaniem odpowiedzialności na operatorów. Państwo, pełniące rolę gwaranta bezpieczeństwa, próbuje zepchnąć odpowiedzialność na prywatne firmy ochroniarskie". Referenci podkreślili fakt, że należałoby wyznaczyć proporcje odpowiedzialności podmiotów prywatnych i publicznych za ochronę infrastruktury krytycznej. Dr Michał Brzeziński z Instytutu Nauk Politycznych UW wystąpił z referatem „Potrzeby bezpieczeństwa a popularność prywatnego sektora ochrony”. Udzielił w nim odpowiedzi na pytania: „czym są potrzeby bezpieczeństwa, co wyróżnia potrzeby bezpieczeństwa i co z nich wynika". Referent przypomniał uczestnikom o istocie odczuwania zagrożeń przez człowieka i ich negatywnym wpływie na zdrowie psychiczne. Mgr Anna Walkowiak z Fundacji Panoptykon przedstawiła wyniki ankiety, z której wynikało, że co druga osoba badana w Polsce obawia się o siebie i swoich bliskich, co bezpośrednio stanowi o zapotrzebowaniu na usługi ochroniarskie. Referentka apelowała o to, by: „,...) zostały ustanowione standardy chroniące prawa obywateli w zakresie usług detektywistycznych, zasady chroniące interes publiczny, by nie stać na straży tylko interesu firm, ale również obywateli, ponieważ działalność detektywów dotyka szerszej grupy osób". Dr Joanna Buchalska z ALK przedstawiła referat „Wywiad gospodarczy a prawo do prywatności”. Zaznaczyła, że w prawie polskim nie ma klarownego zapisu o tym, gdzie kończą się uprawnienia detektywa. Pani doktor sformułowała wniosek, że: „ustawa o usługach detektywistycznych zawiera luki, a prawo do prywatności jest normą nadrzędną w kontekście działalności detektywów". Dyskusja została zdominowana właśnie przez to wystąpienie, albowiem środowisko detektywów skupiło się na wypowiedzi dr Joanny Buchalskiej i uznało jej wystąpienie za atak, tudzież za uświadomienie samym detektywom ich kompetencji.

Sesję kolejną otworzył dr Andrzej Mikstal z Biura Informacji Renoma II referatem zatytułowanym: „Bezpieczeństwo informacyjne przedsiębiorstw w praktyce firmy detektywistycznej". Referent wyjaśnił, jakie sposoby stosują profesjonalne firmy detektywistyczne w celu wyeliminowania możliwości kradzieży informacji. Mgr Janusz Raczyński, przedstawiciel Securitas Polska i dyrektor na Polskę IBA, $\mathrm{w}$ wystąpieniu poruszył zagadnienia form współdziałania firm ochrony z państwem w odniesieniu do nowej strategii bezpieczeństwa narodowego. Określił problem niedoprecyzowania różnych zagadnień w systemie prawnym związanych z ochroną infrastruktury krytycznej przez prywatne firmy ochrony, ale również wskazał możliwości, jakie taka współpraca mogłaby przynieść, np.: „Można wykorzystać 
wiedzę pracowników ochrony do obrony danego obiektu lub podczas ewakuacji". Zaznaczył, że współpraca państwa z prywatnymi podmiotami nie powinna być jednostronna. Państwo mogłoby zaproponować pracownikom ochrony szkolenia w jednostkach wojskowych. Ostatnimi referentami tej części konferencji były studentki prawa ALK: Małgorzata Bojsza, Żaneta Kozłowska i Justyna Szymkowicz, które przedstawiły wyniki badań prowadzonych w centrach handlowych, muzeach i na stadionie z pracownikami ochrony: „Ochrona pod lupą. Czego nie wiedzą klienci centrów handlowych - taśmy z wideokamer, zarys kompetencji pracownika ochrony obiektu, szefowie agencji". Podczas panelu dyskusyjnego ważną kwestię podniosła dr Katarzyna Staszyńska-Zagórska z ALK. „Branża pracowników ochrony musi postarać się o poprawę wizerunku i wynagrodzenia pracownika, zabiegać o przychylność opinii publicznej".

Sesję wieczorną rozpoczęło wystąpienie mgr. Mariana Szłapy, dyrektora Prywatnego Biura Śledczego DETECTIO, pt.: „Uwagi de lege lata do ustawy o usługach detektywistycznych”. Referent stwierdził: „Rzeczywistość prawna polskiego detektywa i jego praca odbywa się w bardzo nieprecyzyjnej rzeczywistości prawnej". Skrytykował ustawę o usługach detektywistycznych, która niejednokrotnie podczas konferencji była negatywnie oceniana, wykazując, że dała detektywowi tylko jedno uprawnienie: możliwość pozyskiwania, przetwarzania i wykorzystywania informacji o osobach bez ich wiedzy. „Państwo jest zobowiązane do tworzenia dobrego prawa, a prawodawca nie może uczciwych ludzi ciężko pracujących w tym zawodzie spychać do szarej strefy". Mgr Zdzisław Mazurski z Perfect Business Consulting przedstawił zagadnienie szkoleń detektywów po deregulacji. Podczas swojego wystąpienia nawiązał do formy egzaminu na detektywa przed deregulacją. Referent postulował podwyższenie poziomu wiedzy, którą musi posiadać osoba ubiegająca się o licencję detektywa. Mgr Eugeniusz Kazienko, sekretarz Zarządu Polskiego Stowarzyszenia Licencjonowanych Detektywów, opisał działalność detektywistyczną w praktyce. Bazując na przykładach z życia, przedstawiając konkretne sprawy prowadzone przez detektywów, obnażył ułomność prawa w zakresie rozpatrywanym podczas konferencji (brak ustawy o monitoringu wizyjnym, nieaktualna ustawa o usługach detektywistycznych itp.). Na zakończenie dr Julia Bartczak z UKSW zaprezentowała temat: „Etyczne kwestie ochrony bezpieczeństwa i porządku publicznego w sektorze prywatnym w Polsce”. W końcowej dyskusji powróciło zagadnienie napisania nowej ustawy o usługach detektywistycznych. Głosy w tej sprawie były podzielone. Jedni uważali, że taka zmiana w chwili obecnej nie jest możliwa do przeprowadzenia, wykazywali, że każda deregulacja zawodu powoduje osłabienie homogenicznej w swojej strukturze organizacji i obecna władza nie ma interesu w zajmowaniu się tą kwestią. Uznali deregulację za zamysł polityczny wymierzony w korporacyjność. Inni zaś byli 
nastawieni optymistycznie, postulowali możliwość dokonania wszystkiego, by uzdrowić sytuację zarówno branży detektywistycznej, jak i branży ochrony, w kooperacji z nową władzą.

Konferencję można uznać za bardzo udaną. Różnorodność poglądów, uwarunkowana profesjami referentów i zaproszonych gości zabierających głos w dyskusji, pozwoliła na zrealizowanie celów konferencji. Dyskusje ubarwiały całe wydarzenie i świadczyły o tym, że temat jest aktualny. Oprócz czterech części konferencji naturalnie miały miejsce przerwy i to właśnie podczas rozmów kuluarowych referenci mogli doprecyzować swoje wypowiedzi, w zaciszu skonfrontować swoje poglądy z odmiennymi. Zwieńczeniem powyższego sprawozdania mogą być słowa Cycerona: „Lecz ponieważ (...) mamy się rozejść, zachowajmy w pamięci nasze rozmowy". I, dopowiedzmy, zachowajmy w pamięci nasze rozmowy, ale także przekujmy je w działanie. 